\title{
Paradigma Pendidikan Agama Islam di Era Globalisasi Menuju Pendidik Profesional
}

\author{
Zulkifli Lubis \\ Universitas Negeri Jakarta \\ Zulkifli-lubis@unj.ac.id \\ Dewi Anggraeni \\ Universitas Nahdlatul Ulama Indonesia, DPK Universitas Negeri Jakarta \\ Dewianggraeni@unusia.ac.id
}

\begin{abstract}
Islamic Education in the globalization eras makes an opportunity to fill the moral and spiritual emptiness of modern humans in another side has a challenge when its inability to respond to various crises and discussions. The era of globalization with all the elements, encourage variety of new paradigms in Islamic religious education through various types of educational components, so that Islamic education can provide the right answers to various challenges in accordance with the times. The method used in this study is a literature review, with primary sources of Islamic Education; Tradition and Modernization in the Middle of the Challenge of Millennium III. As well as Law No. 14 of 2005 concerning teachers and lecturers. The results of this study conclude that to face the challenges of globalization of Islamic education requires human resources who have quality, through professional educators and have a work ethic and high commitment, have leadership spirit, become role models, motivators, broadminded, creative and democratic. Which is illustrated through professionalism in design and learning models, planning and evaluation of learning.
\end{abstract}

Keywords: Islamic Education, Professional educators, Globalization eras

\begin{abstract}
Abstrak
Pendidikan Agama Islam di era globalisasi menjadikan peluang untuk mengisi kekosongan moral dan spiritual manusia modern di satu sisi sebagai tantangan ketika ketidak mampuannya menjawab berbagai krisis serta pembahruan yang dihadapi. Era globalisasi dengan segala unsur yang ada di dalamnya, melahirkan berbagai paradigma baru dalam Pendidikan Agama Islam melaui berbabagai macam kompenen pendidikan, sehingga pendidikan Agama Islam bisa memberikan jawaban yang tepat atas berbagai tantangan sesuai dengan zamannya. Metode yang digunakan dalam kajian ini adalah kajian pustaka (litelatur research), dengan sumber primer Pendidikan Islam; Tradisi dan Modernisasi di Tengah Tantangan Milenium III. Serta UU No.14 Tahun 2005 mengenai guru dan dosen. Hasil penelitian ini menyimpulkan bahwa untuk menghadapi tantangan globalisasi pendidikan Agama Islam membutuhkan SDM yang hadal dan berkualitas, lewat pendidik yang professional serta memiliki etos kerja dan komitmen yang tinggi, memiliki jiwa kepemimpinan, menjadi teladan, motivatoris, berwawasan luas, kreatif dan demokratis. Yang tergambar melaui profesionalitas dalam desain serta model pembelajara, perencanaan serta evaluasi pemeblajaran.
\end{abstract}

Kata Kunci: Pendidikan Agama Islam, Pendidik profesional, Era globalisasi 


\section{A. Pendahuluan}

Era globalisasi, dewasa ini dan di masa datang, sedang dan terus mempengaruhi perkembangan social dan budaya masyarakat muslim Indonesia umumnya, atau pendidikan Islam secara khusus. Secara tidak langsung hal ini menuntut masyarakat muslim untuk survive dan berjaya di tengah perkembangan dunia yang kian kompetetif di masa kini dan abad ke 21. Milenium 21 adalah peradaban yang banyak didominasi oleh kemajuan ilmu pengetahuan dan teknologi. Mengutip istilah Azyumardi Azra tanpa harus menjadikan sains sebagai"pseudo-religion" maju mundurnya masyarakat di masa kini dan mendatang sangat bergantung kepada sains. Dengan demikian, hal ini menjadi tantangan tersendiri bagi masyarakat muslim secara spesifik untuk mengembangkan sains dan teknologi khususnya terkait muatan Pendidikan Agama Islam ${ }^{1}$.

Pendidikan agama Islam di era globalisasi ditandai dengan kuatnya terkanan ekonomi dalam kehidupan, tuntunan masyarakat untuk memperoleh perlakuan yang makin adil dan demokratis, penggunaaan teknologi canggih, saling ketergantungan, serta kuatnya nilai budaya yang hedonistic, pragmatis, materialistic, dan sekuleristik ${ }^{2}$. Masih menurut Abuddin Nata, bahwa era globalisasi dapat dipahami sebagai suatu keadaan yang ditandai oleh adanya penyatuan politik, ekonomi, social, budaya, ilmu pengetahuan, teknologi, dan infromasi yang terjalin satu sama lain antar Negara dengan tanpa menghilangkan identitasnya masing-masing. Penyatuan ini terjadi berkat kemajuan teknologi Informasi (TI) yang dapat menghubungakan dan mengkomunikasikan setiap isu yang ada pada suatu Negara dengan Negara lainnya. Munculnya berbagai kecenderungan dalam era globalisasi merupakan tantangan sekaligus peluang jika mampu dihadapi dan dipecahkan dengan arif dan bijaksana. Oleh karenanya, umat Islam harus siap untuk menghadapi dan meningkatkan kemampuan di bidang konsep, kemampuan di bidang komunikasi, kemampuan menejemen dan kepemimpinan, kemampuan di bidang emosional dan institusi, kemampuan di bidang moral dan kemampuan di bidang spiritual sehingga dapat merumuskan kembali berbagai komponen dalam pendidikan ${ }^{3}$.

Misi utama pendidikan, membentuk manusia seutuhnya dengan menyeimbangkan segala potensinya tidak terlepas dari pengaruh di era golbalisasi. Tujuan pembangunan Indonesia sendiri untuk mewujudkan manusia yang sejahtera lahir dan batin, penguasaan

${ }^{1}$ Azyumardi Azra, Pendidikan Islam Tradisi Dan Modernisasi Di Tengah Tantangan Milenium III (Jakarta: Kencana Prenada Media Group, 2012), 41.

${ }^{2}$ Abuddin Nata, Kapita Selekta Pendidikan Islam, 1st ed. (Depok: PT Raja Grafindo Persada, 2012), 7.

${ }^{3}$ Abuddin Nata, Teori Dan Perilaku Organisasi Pendidikan Islam (Jakarta: UIN Jakarta Press, 2011), $21-26$ 
atas sains dan teknologi memerlukan perspektif etis dan panduan moral hal ini yang kemudian memunculkan dinamika baru dalam pendidikan Islam yakni, usaha meninjau kembali seluruh komponen pndidikan secara inovatif, keratif, progresif, holistic, dan adaptif dengan tuntunan modernitas.

Pendidikan dalam Islam berlandaskan sumber-sumber yang jelas dan mapan. Pemahaman, penafsiran, dan penjelasan megenai sumber-sumber ajaran Islam membutuhkan ilmu pengetahuan yang otoritatif. Al-Qur'an sendiri mengisyaratkan untuk bertanya kepaa merka yang mengetahui dalam yang diisyaratkan dengan ahl al dzikri. Konsultasi kepada mereka yang memiliki ilmu pengetahuan dan agama menjadi kewajiban bagi seorang muslim. Al-Qur'an sendiri mengisyaratkan bahwa orang-orang yang berilmu ditinggikan beberapa derajat dengan memilki derajat pengetahuan, kebijaksanaan dan pengalaman spiritual sehingga mendorong manusia untuk mengamalkan ilmunya dan berbuat ihsan $^{4}$. Oleh karenanya, Islam sangat memberikan perhatin kepada pendidik. Pendidik dalam kancah peradaban umat manusia mempunyai peranan yang teramat penting, dimana pendidik berperan sangat besar dalam membentuk majunya suatu bangsa, yakni maju dalam segi akhlak dan moral, maju dalam bidang iptek, dan sebagainya. Dengan kata lain, bahwa pendidik merupakan lampu penerang dan penunjuk jalan bagi bangsa yang ingin maju.

Dalam perjalanan sejarah, peradaban umat manusia tidak terlepas dari peran pendidik. Nabi Muhammad Saw dalam melaksanakan fungsinya sebagai pendidik utama tidak hanya dibekali oleh Al-Qur'an semata sebagai petunjuk dalam menjalankan kehidupan melainkan dibekali juga dengan kepribadian dan karakter istimewa. Beliau adalah orang yang suka melakukan refleksi dan merenung tentang alam lingkungan, masyrakat sekitar dan Tuhan; beliau adalah orang yang senantiasa belajar school with out wall. Dengan kepribadian yang mulia dan terpuji, serta suka mencari hikmah, seseorang dapat fungsional pendidik berhasil ${ }^{5}$. Misi kependidikan pertama yang dibawa oleh Rasulullah Saw sebagai pendidik sekaligus Rasul adalah penanaman akidah yang benar, yakni mengesakan Tuhan, dengan memahami seluruh fenomena alam dan kemanusiaan sebagai suatu kesatuan yang holistik. Pejalanan hidup nabi Muhammad di Makkah sebagai seorang pendidik yang utama tergambar dalam membangun misi masyarakat yang bertauhid; meletakan dasar-dasar fundamental bagi pembentukan nucleus masyarakat historis yang mampu menjawab tantangan zaman. Sementara perjalanan hidup Rasulullah Saw di Madinah sebagai pendidik

\footnotetext{
${ }^{4}$ Naquib al Attas, Filsafat Dan Praktik Pendidikan Islam (Bandung: Mizan, 2013), 225.

${ }^{5}$ Azra, Pendidikan Islam Tradisi Dan Modernisasi Di Tengah Tantangan Milenium III, 62.
} 
utama tergambar dalam pembangunan masyarakat sosial-politik serta membangun tradisi pendidikan Islam dengan fungsionalisasi masjid. Sehingga pendidikan yang berdasarkan manhaj rabani inilah yang dapat membentuk manusia yang beriman, berilmu, dan beramal; cakap secara lahiriah dan batiniah; berkualitas secara emosional dan rasional, atau dengan kata lain memilki keseimbangan antara EQ dan $\mathrm{IQ}^{6}$.

Spirit misi propetis diadposi oleh para cendikiawan muslim yang telah terkemuka di dunia akademik seperti berbagai macam kontribusi yang diberikan dalam dunia pendidikan dan teknologi serta penemuan-penemuan ilmiah seperti; al-Farabi, Ibnu Sina, Ibnu Khaldun, Ibn Rusdy dan lain sebagainya. Mereka memiliki andil yang luar bisa dalam membentuk masyarakat yang berilmu pengetahuan dan berteknologi di era moderen. Spirit misi propertis ini tidak hanya menjiwai cendekiawan muslim di Timur melainkan juga menjiwai para tokoh pendidik di Tanah Air. K.H. Ahmad Dahlan, K.H. Hasyim Asy’ari, Ki Hajar Dewantoro, dan serta para tokoh lainnya yang ikut melahirkan generasi bangsa Indonesia yang maju, cerdik pandai, berani, serta mampu membentuk dan membangun negara Republik Indonesia yang merdeka. Dilihat dari segi kepribadian, mereka adalah orang-orang yang berkepribadian luhur serta ikhlas beramal. Luhurnya pribadi serta ikhlasnya beramal itulah yang menyebabkan mereka berhasil membentuk dan mempersiapkan generasi penerus yang berbudaya luhur. Pantaslah bila mereka mendapat gelar sebagai "Pahlawan Tanpa Tanda Jasa".

Pendidik, guru adalah agen pembaharuan dalam segala bidang, mereka berada pada barisan terdepan menyongsong dunia baru yang melahirkan manusia bermutu yang menguasai ilmu pengetahuan dan sekaligus menjaga peradaban manusia melalui sifat luhur dan kepribadian yang baik. Begitu penting dan mulianya guru hingga pakar pendidikan berpendapat: "andai tidak ada kurikulum yang tertulis, tidak ada ruang kelas dan prasarana belajae mengajar namun ada guru, maka pendidikan masih tetap berjalan"7. Guru tak ubahnya seperti pendeta atau orang suci yang begitu dihormati, merek menjadi tempat bertanya bagi masyarakat. Visi orientasi guru sebagai pendidik serta kebahagiaannya adalah membangun peradaban dengan cara memajukan dan mesejahterakan masyarakat melalui peningkatan kualitas fisik, panca indra, akal pikiran, sosial, seni, moral dan spiritual.

\footnotetext{
${ }^{6}$ Azra, Pendidikan Islam Tradisi Dan Modernisasi Di Tengah Tantangan Milenium III, 62-63.

${ }^{7}$ Nana Syaodih Sukmadinata, Pengembangan Kurikulum (Bandung: Rosda Karya, 1997), 89.
} 
Kebahagiaan seorang guru adalah apabila melihat anak didiknya menjadi orang sukes di masyarakat yang melaksanakan peran dan fungsinya mamajukan masyarakat ${ }^{8}$.

Dampak era globalisasi mempengaruhi peran dan fungsi guru yang mengalami perubahan secara drastis dan mendasar akibat dari kemajuan ilmu pengetahuan dan teknologi serta budaya global yang cenderung mengutamakan rasio, panca indara, dan materi yang berbasis pada anthropo-centris yang pada akhirnya mengarah kepada sikap hidup materialisti, hedonistik, sekuleristik, dan pargmatis. Penggunaan sains dan teknologi yang memberi kemanfaatan bagi kehidupan manusia di satu sisi menyebabkan semakin mengecilnya peran dan fungsi guru, bahkan dimensi "sakralitas" seorang guru semakin tergeser. Melihat tugas guru yang sebagai agen perubahan yang dapat menciptakan generasigenerasi unggul, hal ini tidaklah mudah. Terlebih sebagai guru agama yang mana manusia moderen lebih menggunakan rasionalitasnya dan cenderung mengabaikan dimensi spiritualitasnya. Era globalisasi dengan segala dinamika yang ada menjadi peluang dan tantangan bagi pendidik atau guru maka diperlukan profesionalisme sebagaimana yang telah termaktub dalam UU No.14 tahun 2015 tentang guru dan dosen sehingga eksistensinya tidak lekang oleh zaman hal ini sebagaimana yang telah .

\section{B. Metode Penelitian}

Metode yang digunakan dalam kajian ini adalah kajian pustaka (literature research), yaitu segala upaya yang dilakukan oleh penulis untuk memperoleh dan menghimpun segala infromasi yang relevan dengan masalah yang diteliti. Kajian ini memuat beberapa teori yang saling berkaitan sat sama lain yang didukung oleh data-data dari sumber pustaka yang mendukung khususnya mengenai Pendikan di era globalisasi dengan sumber primer Pendidikan Islam; Tradisi dan Modernisasi di Tengah Tantangan Milenium III. Data-data yang dianalisis mengenai profesionalisme guru sebagai pendidik mengacu kepada UndangUndang No.14 tahun 2015 tentang guru dan dosen. Data-data yang ditemukan kemudian di bahas dan dianalisis secara induktif untuk menghasilkan kesimpulan.

\section{Hasil dan Pembahasan}

\section{Paradigma Pendidikan Agama Islam di Era Globalisasi}

Tokoh yang mengembangkan istilah paradigma dalam dunia ilmu pengetahuan adalah Thomas S. Khun, menurutnya paradigma adalah suatu asumsi-asumsi dasar dan

${ }^{8}$ Jhon P Miller, Holistic Learning and Spirituality Education, Braeking New Ground (New York AS: State University of New York Press, 2005). 
teoritis yang umum (merupakan suatu sumber nilai) sehingga merupakan suatu sumber hukum, metode, serta penerapan dalam ilmu pengetahuan sehingga sangat menentukan sifat, ciri serta karakter ilmu pengetahuan sendiri. Secara singkat dapat dikatakan paradigma adalah "carapandang, kerangka berfikir, nilai-nilai atau cara memecahkan sesuatu masalah (dalam suatu bidang tertentu, termasuk dalam bidang pembangunan, reformasi, maupun dalam pendidikan) yang dianut oleh suatu masyarakat pada masa tertentu". Semntara menurut Joel Arthur Barker sebagaimana yang diungkap oleh Azyumardi Azra bahwa: "Paradigama adalah seperangkat peraturan dan kerentuan baik yang tertulis maupun tidak yang berfungsi untuk:1) menciptakan atau menentukan batas-batas; dan 2) menjelaskan cara berperilaku di dalam batas-batas tersebut agar menjadi orang yang berhasil"”.

Paradigama tidaklah mesti statsis sebaliknya harus dinamis, terlebih menyangkut pendidikan yang mana sangat erat kaitannya dengan berbagai aspek kehidupa masyarkat yang senantiasa berubah dan berkembang khususnya di era globaliasasi. Perubahan paradigma menurut Harefa melaui dua cara yakni: 1) inside out, yakni dilakukan secara sadar dan sukarela. Dimana perubahan paradigma dilakukan melalui proses pembelajaran, pendidikan, perluasan wawasan, peningkatan pengalaman dan lain sebagainya. Melaui pola ini paradigama seseorang menjadi berkembang dan dinamis. 2) outside in, yakni sifatnya lebih memaksa, dimana seseorang mengubah atau menggeser paradigmanya agar dapat terhindar dari berbagai bentuk abnormalitas dan deviasi lainnya. Pada konteks ini, era globalisasi telah menyeret paradigma pendidikan dan pembelajaran menuju sesuatu yang baru $^{10}$. Perubahan paradigma dalam pendidikan ini dihimpun oleh Surakhmad dalam Pendidikan Islam yang berorientasi ke masa silam menjadi berorientasi ke masa depan: 1) peralihan dari pendidikan yang mngutamakan nilai kehidupan budaya feudal aristokrasi ke pendidikan yang mengalahkan kehidupan nilai budaya demokratis, 2) peralihan pendidikan yang memihak kepada kepentingan penguasa menuju kepentingan masyarakat, 3) pengalihan pendidikan yang terpusat sentralistik beralih kepada pengelolaan pendidikan berbasis kekuatan masyarakat, 4) peralihan sikap kependidikan yang mengutamakan keseragaman ke sikap pendidikan yang menghargai keberagaman, 5) peralihan pola manajemen yang memupuk ketergantungan masyarakat ke pola manajemen yang mengutamakan kemandirian, 6) peralihan dari pendidikan yang takluk kepada gaya pengusa menuju pendidikan yang menyadarkan masyarakat, 7) peralihan metodologi pendidikan konformisme nilai menuju pendidikan dengan metodologi pengembangan ilmu dan

\footnotetext{
${ }^{9}$ Azra, Pendidikan Islam Tradisi Dan Modernisasi Di Tengah Tantangan Milenium III, 52.
}

${ }^{10}$ Azra, Pendidikan Islam Tradisi Dan Modernisasi Di Tengah Tantangan Milenium III., 54. 
pemanfaatan IPTEK, 8) peralihan pendidikan sebagai pelaksanaan kewajiban kepada penyadaran masyarakat akan pentingnya pendidikan, 9) peraliahan orientasi pendidikan dari sudut kepentingan politik ke orientasi perubahan dan kemajuan, 10) peralihan sikap pendidika yang konformistik ke sikap pendidik ayang motivatif, kreatif dan inovatif, 11) peralihan pola pendidikan yang terutup, isolasionistik menuju pola pendidikan yang tebuka dan fleksibel, 12) peralihan dari pola dan program kuliner yang tradisional menuju pola program kulikuler yang kontekstual. Kerangka perubahan yang ditawarkan oleh Surakhmad memperilhatakan kompleksitas paradigama pendidikan yang seyogyanya dilakukan dalam dunia pendidikan mengadapi era global dan globalisai ${ }^{11}$.

Kedatangan Islam ke Indonesia pada abab ke-6 $\mathrm{M}$ telah mengambil peran yang sangat sigmifikam dalam kegiatan pendidikan. Hal tersebut dilatarbelakangi oleh beberapa factor sebagaimana yang diungkapkan oleh Abuddin Nata ${ }^{12}$;

1) Islam memiliki karakter sebagai agama dakwah dan pendidikan. Dengan karakternya tersebut maka Islam mengajak dan membimbing manusia menuju kepribadian yang sesuai dengan ajaran agama Islam. Hal ini yang mendorong umat Islam membangun system pendidikan melalui pesantren, hingga lembaga-lembaga pendidikan yang bersifat formal. Upaya umat Islam dalam membangun lembaga pendidikan didasari motivasi keagamaan akan kewajiban belajar dan mengajar sebagai bagaian dari ajaran Islam. Membangun dan memajukan pendidikan termasuk ke dalam tugas dan tanggung jawab pemeluk agama Islam ${ }^{13}$.

2) Terdapat hubungan simbiotik fungsional antara ajaran agama Islam dengan kegiatan pendidikan. Hal ini tergambar dalam kesatuan visi, misi serta tujuan pendidikan tidak terlepas dari pondasi utamanya yakni sumber ajaran Islam. Dengan dasar ajaran Islam maka pendidikan yang dikembangkan memiliki watak humanism theosentris, yakni pendidikan yang disadarkan kepada hasil cita, rasa dan karsa manusia yang bersumber dari ajaran agama. Dengan bantuan usaha pendidikan dengan berbagai macam corak dan tingkatannya menyebabkan ajaran Islam membumi dan diamalkan oleh masyarakat ${ }^{14}$.

${ }^{11}$ Azra, Pendidikan Islam Tradisi Dan Modernisasi Di Tengah Tantangan Milenium III, 54-55.

12 Abuddin Nata, Kapita Selekta Pendidikan Islam, 1st ed. (Depok: PT Raja Grafindo Persada, 2012), $7-11$

${ }^{13}$ Abdullah Syukr i Zarkasy, "Madrasah Pemberdayaan Dan Peningkatan Mutu,” MP3A 1, no. 1 (2005): 92.

\footnotetext{
${ }^{14}$ Abuddin Nata, Studi Islam Komperhensif(Jakarta: Prenada Media Grup, 2011), 230.
} 
3) Islam melihat pendidikan sebagai sarana yang paling strategis untuk mengangkat harkat dan martabat manusia dalam berbagai macam bidang kehidupan. Hal ini diisyaratkan dalam ayat yang pertama kali turun, yakni perintah membaca. Secara normative idealitas, ayat al-Qur'an surat al-Alaq ayat 1-5 berkaitan erat dengan masalah pendidikan. Ajaran normative idealitas ini mengambil bentuk perhatian dan kepedulian umat Islam untuk membangaun lembaga pendidikan dengan komponen yang lengkap. Dalam ayat tersebut setidaknya terdapat lima aspek pendidikan yakni: a) aspek proses dan metodologi, yakni membaca dalam arti luas mengumpulkan infromasi, memahami, mengkalsifiaksi, membandingkan, menganalisis, dan memferivikasi; b) aspek pendidik atau guru dalam hal ini adalah guru pertama Allah Swt; c) aspek murid yakni nabi Muhammad Saw dan seluruh umat manusia, d) aspek sarana dan prasarana yang dalam ayat tersebut diwakilkan dengan kata qalam e) aspek kurikulum, yakni mencakup segala hal yang belum diketahui oleh manusia (ma lam ya lam). Kelima komponen tersebut merupakan komponen utama dalam kegiatan pendidikan.

Sesuai dengan perkembangan dan tuntunan zaman, pendidikan Islam telah menampilkan dirinya sebagai pendidikan yang fleksibel, responsive, dan sesuai dengan perkembangan zaman, berorientasi kepada masa depan, seimbang, berorientasi pada mutu yang unggul, egaliter, adil, demokratis, dinamis. Sejarah menunjukan bahwa pendidikan Islam senantiasa mengalami inovasi dari waktu ke waktu. Melalu inovasi inilah pendidikan Islam saat ini muncul dengan berbagai model yang beragam. Bagi umat Islam sendiri, era globalisasi dalam arti tukar menukar dan transmisi ilmu pengetahuan, budaya, dan peradaban bukanlah hal yang baru. Sejuah ini sejarah mencatat tedapat tiga fase dimana era globalisasi telah dilalui dan dijalankan dalam pendidikan dunia Islam. Fase pertama, pada zaman klasik (abad ke-6 s/d 13M) umat Islam telah membangun hubungan dan komunikasi yang intens dan efektif dengan berbagai macam pusat peradaban dan ilmu pengetahuan yang ada di dunia. Hasil komunikasi tersebut mengantarkan umat Islam menuju peradaban dengan bingkai ilmu pengetahuan dimana lahir berbagai cendekiawan muslim yang memberikan sumbangsih dan kontribusi bagi dunia. Fase kedua, zaman pertengahan (abad ke-13 s/d 18M) Umat Islam membangun hubungan dengan Eropa dan Barat. Umat Islam memberikan kontribusi yang besar bagi kemajuan Eropa. Hal ini sebagaimana yang ditulis oleh W.C. Smith, dan Thomas W. Arnold bahwa kemajuan Eropa tidak terlepas dari kontribusi umat Islam lewat penerjemahan berbagai disiplin kelimuan yang kemudian dikembangakan di Barat. Fase ketiga, di zaman modern (abad ke-19 hingga saat ini) dimana muncul kesadaran 
umat Islam untuk kembali membangun peradabannya melalui ilmu pengetahuan, budaya dan teknologi dengen berbagai kajian dan penelitian. Umat Islam mulai memperlajari berbagai kemajuan yang dicapai oleh Eropa dan Barat dengan senatiasa mengedepankan nilai-nilai estetika dan moral sebagai cerminan dari karakteristik Islami.

Untuk menangkal pengaruh negatif dari globalisasi tersebut salah satu upaya yang dilakukan adalah melalui jalur pendidikan, terutama pendidikan agama Islam. Dengan adanya pendidikan agama diharapkan peserta didik memiliki kepribadian yang utama Pendidikan agama bertujuan untuk membentuk insan kamil (kesempurnaan insani) yang bermuara pada pendekatan diri kepada Allah dan kebahagiaan dunia dan akhirat. Pendidikan agama juga diharapkan mampu membentuk kesadaran diri peserta didik sebagai hamba Allah sekaligus fungsinya sebagai khalifah di bumi ${ }^{15}$. Dalam menghadapi krisis global, terutama krisis dalam bidang ekonomi, politik dan sosial. Pendidikan agama Islam diharapkan mampu memberikan solusi dalam memperbaiki akhlak/moral masyarakat. Sehingga wajar apabila bangsa Indonesia yang berbasis dan bersikap religius menempatkan pendidikan agama sebagai bagian yang sangat penting bagi pengembangan sistem pendidikan nasional. Sebagian besar anggota masyarakat Indonesia masih meyakini bahwa ajaran agama menjadi pilar utama pembangunan moral bangsa ${ }^{16}$.

Senada dengan pendapat di atas, Haidar Bagir mengemukakan bahwa kegagalan pendidikan agama disebabkan oleh dua hal. Pertama, Pengajaran pendidikan agama selama ini dilakukan secara simbolik-ritualistik. Agama diperlakukan sebagai kumpulan simbolsimbol yang harus diajarkan kepada peserta didik dan diulang-ulang, tanpa memikirkan korelasi antara simbol-simbol ini dengan kenyataan dan aktivitas kehidupan di sekitar mereka. Kedua, pendidikan agama dinilai gagal karena mengabaikan syarat-syarat dasar pendidikan yang mencakup tiga komponen; intelektual, emosional, dan psikomotorik. Pendidikan agama hanya terfokus pada aspek kognis (intelektual-pengetahuan) semata, sehingga ukuran keberhasilan peserta didik hanya dinilai ketika mampu menghafal, menguasai materi pendidikan, bukan bagaimana nilai-nilai pendidikan agama seperti nilai keadilan, tasamuh, dan silaturrahmi, dihayati (mencakup emosi) sungguh-sungguh dan kemudian diproaktifkan (psikomotorik). Akibat pola pendidikan semacam ini tidak menjadikan peserta didik sebagai manusia yang semakin tawadlu, manusia yang shaleh

15 Fathiyah Hasan Sulaiman, Al-Mahabut Tarbawi Inda Al-Ghazali (Sistem Pendidikan Versi AlGhazali, ed. Fathurrahmat (Bandung: Al Ma'arif, 1986).

16 Shindunata, Menggagas Pardigma Baru Pendidikan Demokratisasi, Otonomi, Civil Society, Globalisasi (Yogyakarta: Kanisius, 2000), 216. 
secara individual maupun social ${ }^{17}$. Di samping itu pula, akibat pola pendidikan agama yang semacam ini menjadikan manusia terasing dari agamnya bahkan dengan kehidupannya sendiri. Mereka hanya mengenal agama sebagai klaim-klaim kebenaran sepihak. Mereka terperangkap dengan pemahaman ajaran agama yang bersifat permukaan dan bersifat legalformalistik yang hanya terkait dengan persoalan halal-haram, iman-kafir, surga-neraka. Sedang ajaran dasar agama yang syarat dengan nilai-nilai spiritual dan moralitas, semisal kedamaian dan keadilan, menjadi terbengkalai, tidak pernah disentuh secara serius. Akibatnya, pesan dan misi agama yang bersifat pereneal terbenam dibalik keberagamaan eksklusif $^{18}$.

Pendidikan Agama Islam di era globalisasi menjadikan peluang untuk mengisi kekosongan moral dan spiritual manusia modern disatu sisi sebagai tantangan ketika ketidakmampuannya menjawab berbagai krisis serta pembahruan yang dihadapi. Era globalisasi dengan segala unsur yang ada di dalamnya, melahirkan berbagai paradigma baru dalam Pendidikan Agama Islam melaui berbabagai macam kompenen pendidikan, sehingga pendidikan Agama Islam bisa memberikan jawaban yang tepat atas berbagai tantangan sesuai dengan zamannya. Oleh karenanya, pendidikan Agama Islam membutuhkan SDM yang hadal dan berkualitas, lewat pendidik yang profesional serta memiliki etos kerja dan komitmen yang tinggi, menejemen berbasis system dan infrastuktur yang kuat, sumber daya yang memadai, serta standar yang unggul. Dengan usaha yang sungguh-sungguh dan menegmbangkan berbagai model pembelajaran serta pemanfaatan teknologi Pendidikan Agama Islam akan tetap pada eksistensinya, serta dapat merubah tantangan menjadi peluang.

\section{Pendidik atau Guru Agama Islam Profesional}

Profesi pendidik atau guru merupakan tugas mulai dalam ajaran agama Islam, mentransfer ilmu pengetahuan kepada orang lain adalah ibadah. Bahkan keistimewaan menjadi guru tergambar dalam hadis nabi mengatakan bahwa apabila seseorang meninggal dunia terputus amalnya kecuali tiga macam, yaitu: satu, infak/ shadaqah (yang dilakukannya sewaktu hidupnya) dua, anak yang shaleh / shalehah yang mendoakan kedua orang tuanya, tiga, ilmu yang bermanfaat (yang diajarkannya kepada orang lain). Banyak guru yang merasa senang bisa mengajar, dan merupakan panggilan jiwa, merasa enjoy dengan pekerjaannya. Tetapi tidak sedikit yang merasa biasa-biasa saja atau malah merasa sangat terpaksa. Mengajar baginya adalah karena tiada tempat yang dapat menerimanya sebagai karyawan, menjadi guru adalah pilihan terakhir, akibatnya jadilah guru sekedar melaksanakan tugas,

${ }^{17}$ Abdul Khobir, "Pendidikan Agama Islam Di Era Globalisasi," Forum Tarbiyah 1, no. 1 (2009): 5-6.

${ }^{18}$ Abd A'la, "Pendidikan Agama Yang Mencerahkan," Kompas (Jakarta, 2002). 
dari pada tidak punya kerjaan. Bisa ditebak apa hasil yang diharapkan dari seorang guru / pendidik yang asal-asalan.Apa yang bisa diharapkan dari seorang guru yang tidak mempunnyai misi dan visi dalam pendidikan khususnya pendidikan agama Islam. Padahal untuk menjawab tantangan era globalisasi seorang guru dituntut untuk bekerja profesional.

Kondisi sekarang, dibalik sebagian guru yang bermartabat, berkepribadian yang luhur sesuai dengan tuntunan agama Islam, menjadi suri teladan bagi orang lain khusus anak didiknya, dicintai, dihormati. Tidak sedikit kepribadian dan wibawa seorang guru yang dahulu amat luhur dan disegani, kini tampaknya semakin surut. Yang demikian itu dapat kita lihat dalam kehidupan kita sehari-hari, khususnya dalam kehidupan lembaga pendidikan. Ada seorang guru yang tercela pribadinya, hilang wibawanya, dilecehkan para muridnya, dibenci, dan bahkan ditinggalkan oleh murid-muridnya. Kesemuanya itu merupakan gambaran dari konsekuensi pekerjaan seorang guru/pendidik. Jadi permasalahan yang muncul adalah bagaimana caranya menjadi seorang guru/ pendidik: Pendidikan Agama Islam Profesional?. Guru sebagai pembentuk akhlak, moral yang dapat diteladani oleh anak didiknya. Permasalah inilah yang perlu dicari solusinya untuk dapat menjadikan guru sebagai pribadi yang perlu diteladani, guru yang uswatun khasanah sekaligus guru yang profesioanal.

Paradigma baru guru/pendidik sangat diperlukan, karena boleh dikatakan guru melakukan kegiatan mengajar dengan kondisi yang nyaris tidak berubah dari waktu ke waktu. Namun di sisi lain, tuntutan lapangan terus berubah, bergulir sesuai dengan perkembangan zaman. Oleh karena itu, tiada pilihan lain bagi pendidik kecuali meningkatkan profesionalisme, lulusan yang baik harus didukung oleh para guru yang profesional. Untuk menjadi seorang guru, mudah. Tetapi untuk menjadi seorang guru profesional diperlukan persyaratan yang menyertainya.

Mengacu kepada Undang-undang No. 14 Tahun 2015 tentang guru dan dosen termaktub prinsip profesionlitas guru dimana, guru merupakan bidang pekerjaan khusus yang dilaksanakan berdasarkan prinsip-prisnip profesionlitas. Oleh karennya guru dituntut untuk; memiliki bakat, minat, panggilan jiwa, dan idealisme; memiliki komitmen untuk meningkatkan mutu pendidikan, keimanan, ketakwaan, dan akhlak mulia; memilki kualifikasi akademik dan latar belakang pendidikan sesuai dengan bidang tugas; memiliki kompetensi yang diperlukasn sesuai dengan bidang tugas; memiliki tanggung jawab ata pelaksanaan tuga keprofesionalan; memperoleh penghasilan yang ditentuan kesuai dengan prestasi kerja; memilki kesempatan untuk mengembangkan keprofesionalan secara berkelanjutan dengan belajar sepanjang hayat; memiliki jaminan perlindungan hukum dan 
melaksanakan tugas keprofesionalan; memilki organisasi profesi yang mempunyai kewenangan mengatur hal-hal yang berkaita dengan tugas keprofesionalan guru ${ }^{19}$.

Pendidik Agama Islam professional bekaitan dengan tugas ke profesionalannya yang menitik beratkan kepada kompetsensi profesional yakni nilai karakter penguasaan bidang ilmu yang menjadi tanggung jawabnya, oleh karenanya berkaitan dengan profesionlisme guru atau pendidik harus mengetahui model pendidikan apa yang harus diterapkan untuk pembelajaran, membuat rencana tertulis atau tidak tertulis dan mengevaluasi keberhasilan pendidikan. Keberhasilan belajar seseorang sangat dipengaruhi oleh banyak faktor. Secara garis besar dikelompokkan menjadi dua, yaitu faktor eksternal dan faktor internal. Faktor eksternal yaitu faktor yang berada diluar diri anak, seperti lingkungan rumah, lingkungan masyarakat dan sekolah. Sedangkan faktor internal adalah faktor yang datang dari dalam diri anak sendiri. Kesehatan fisik, kecerdasan, minat, bakat, kemauan, sikap dan motivasi adalah diantara kondisi internal yang akan banyak mempengaruhi belajar anak.

\section{a. Urgensi Modeling dalam Pendidikan}

Menurut Sistem Pendidikan Nasional (Sisdiknas) No. 2 Tahun 1989, pendidikan ialah usaha sadar untuk mempersiapkan peserta didik melalui kegiatan bimbingan, pengajaran dan atau latihan demi peranannya dimasa yang akan datang. Sedangkan tujuan pendidikan yang tercantum dalam GBHN adalah untuk meningkatkan sumber daya manusia, yaitu manusia Indonesia yang beriman, taqwa kepada Tuhan Yang Maha Esa, berbudi luhur, berkepribaidan, disiplin, kerja keras, tangguh, bertanggung jawab, mandiri, cerdas, trampil, dan sehat jasmani dan rohani.

Konsep pendidikan berjalan seiring dengan metode pendidikan, disinilah urgensinya model pendidikan yang diperlukan untuk sampai kepada tujuan dari pendidikan yang itu sendiri. Model pendidikan dari zaman dahulu sampai saat ini masih ada yang relevan dengan pendidikan modern yang sangat menonjol adalah hubungan pendidik dan anak didik yang interaktif bernilai edukatif dalam proses belajar-mengajar. Hubungan antara pendidik dan anak didik yang interaktif bernilai edukatif ini menjadi perhatian kita bersama dan juga menjadi perhatian pendidikan modern guna tercapainya tujuan pendidikan.

Diantara metode-metode pendidikan yang penting, antara lain:

1) Metode bertahap, (gradual, tadrij)

2) Metode bermaian (games - la'ibun)

${ }^{19}$ Agus Fakhrudin, "Nilai-Nilai Karakter Dalam Kebijakan Nasional Pengeloaan Guru," in The First Internatonal Conference on Islamic Education (Bandung: Prodi Pendidikan Ilmu Agama Islam UPI, 2016), $71-72$. 
3) Metode dialog (al-khiwar) dan diskusi (munaqasyah)

4) Metode wisata (al-rihlah)

5) Metode Keteladanan (qudwah)

Setiap metode pendidikan itu tentu keberhasilannya tergantung kondisi anak didik, jadi urutan metode bukanlah merupakan urutan rangking. Metode adalah merupakan cara dalam menyampaikan pesan-pesan yang ingin disampaikan. Supaya pesan-pesan itu sampai dengan baik, tentu seorang guru harus mempersiapkan diri dengan sebaik-baiknya dengan cara :

1) Meningkatkan kualitas guru, antara lain membekali mereka dengan berbagai disiplin ilmu dan keterampilan yang bermanfaat.

2) Dalam menunjang keberhasilan proses belajar-mengajar, perlunya seorang pendidik mempelajari perkembangan akal anak didik untuk tujuan pendidikan karena persiapan (preparedness) dalam menerima dan memahami ilmu muncul secara bertahap (gradual).

3) Hukuman berat yang diberikan pendidik kepada anak didik, terutama terhadap anak didik yang masih kecil dapat menimbulkan pengaruh negatif, menjadikan mereka malas belajar, berdusta dan berpura-pura.

4) Dalam proses belajar-mengajar seorang pendidik hendaklah mempergunakan contoh-contoh yang lebih konkret dan mudah diterima oleh panca indra.

Di samping ide-ide pendidikan yang disebutkan di atas, yang perlu diketahui seorang guru adalah mengetahui perkembangan psikologi seorang anak, kebehasilan seorang anak bukan hanya ditentukan oleh faktor bakat/heriditasi, akan tetapi juga sangat ditentukan oleh faktor lingkungan. Keberhasilan pendidikan ditentukan oleh kerjasama yang baik kedua faktor tadi dan faktor-faktor penting lainnya. Disinilah guru diposisikan sebagai uswah hasanah.

Guru sebagai waratsatul anbiya' mempunyai fungsi untuk menjadi pengelola (manager of learning), pengarah belajar (director of learning), dan fasilitator (the planner of future society). Sehingga pada perannya, guru harus mampu menjadi pemimpin, pembimbing, pengawas, pendamping di dalam mempelajari dan mencoba sesuatu bahan yang diperlukan untuk memenuhi kebutuhan hidupnya, disamping sebagai perencana bagi kehidupan masyarakat, sehingga konsep-konsep yang diajarkan bukan saja berlaku pada waktu proses pendidikan itu berjalan, tetapi juga dapat menjadi pedoman kehidupan seharihari dan pola untuk membina dan mengembangkan hidupnya pada masa yang akan datang. 
Adapun model-model penciptaan nuansa religius dalam pembelajaran PAI menurut Muhaimin adalah sebagai berikut ${ }^{20}$ :

1) Model Struktural Penciptaan suasana religius yang disemangati oleh adanya peraturan, pembangunan kesan, baik dari dunia luar atas kepemimpinan atau kebijakan suatu lembaga pendidikan suatu organisasi.

2) Model Formal Penciptaan suasana religius yang didasari pemahaman bahwa pendidikan agama adalah upaya manusia untuk mengajarkan masalah kehidupan akhirat saja atau ruhani saja. Implikasinya terhadap pengembangan PAI, lebih berorientasi pada keakhiratan, dan masalah dunia dianggap tidak penting, menekankan pendalaman ilmu keagamaan sementara iptek dianggap terpisah dari agama.

3) Model Mekanik Penciptaan suasana religius yang didasari pemahaman bahwa kehidupan terdiri atas berbagai aspek, dan pendidikan dipandang sebagai penamana seperangkat nilai kehidupan, yang masing-masing bergerak menurut fungsinya. Model mekanin berimplikasi pada pengembangan PAI yang lebih menonjolkan fungsi moral atau afektif daripada kognitif dan psikomotor.

4) Model Organik Penciptaan suasana religius yang disemangati oleh pandangan bahwa PAI adalah kesatuan atau sistem yang terdiri atas komponen rumit yang berusaha mengembangkan pandangan hidup agamis yang dimanifestasikan dalam sikap hidup dan ketrampilan hidup yang religius. Model ini berimplikasi pada pengembangan PAI yang dibangun dari fundamental doctrins dan fundamental values yang tertuan dalam Al-Quran dan Hadits sebagai sumber pokok. Kemudian bersedia menerima kontribusi pemikiran pada ahli dan mempertimbangkan konteks historitasnya.

\section{b. Urgensi Model Membuat Perencanaan}

Seorang guru / pendidik agama Islam profesional harus memiliki ilmu pengetahuan yang mumpuni, baik dalam bidang ilmu-ilmu keislaman, sejarah, geografi, kimia, biologi, fisika dan lain-lain. Seorang pendidik yang profesional trampil dalam menciptakan metode pengajaran yang variatif serta sesuai dengan situasi dan materi pengajaran. Dengan demikian, pendidik profesioanal harus membuat rencana pengajaran baik tertulis maupun tidak tertulis. Tanpa perencaan yang mantap kekeliruan bisa terjadi. Banyaknya kekeliruan yang dilakukan sesorang pendidik akan mengurangi kepercayaan anak didik kepadanya sehingga anak didik merendahkan dan menyepelekan segala ilmu yang diberikan kepadanya.

${ }^{20}$ Muhaimin, Suti'ah, and Nor Ali, Paradigma Pendidikan Islam: Upaya Mengefektifkan Pendidikan Agama Islam Di Sekolah, ed. Siti Lailan Azizah (Bandung: Rosda Karya, 2012). 
Kekeliruan seorang guru dapat menimbulkan keraguan dalam diri anak didik. Maka perencanaan pendidikan bagi seorang pendidik merupakan hal yang penting sehingga dia dapat meraih simpati dan minat anak didiknya.

Perencanaan pembelajaran PAI hendaknya mengikuti acuan sebagai berikut ${ }^{21}$ :

1) Mengacu pada kualitas pembelajaranPAI. Perbaikan kualitas PAI dimulai dari desain pembelajaran yang baik, sebagaimana hasil penelitian Chair (1998) bahwa kegiatan pembelajaran yang diawali dengan melakukan kegiatan penyusunan perencanaan pembelajaran akan meningkatkan kualitas pembelajaran dan meningkatkan perolehan hasil belajar.

2) Mengacu pada pendekatan system.Memandang PAI bukan secara terpisah-pisah, melainkan sebagai suatu sistem yang memiliki unsur input, proses dan keluaran, komponen atau variabel yang memiliki fungsi yang berbeda-beda, namun antar komponen satu dan lainnya memiliki interelasi dalam mencapai tujuan yang diharapkan.

3) Mengacu pada teori belajar dan pembelajaran. Teori belajar dan pembelajaran yang banyak dijadikan dasar pada saat ini adalah behavioristik, cognitivistic, humanistic dan contructivistic.

4) Mengacu pada belajar perseorangan (individual). Jika PAI tidak dirancang dengan mengacu pada karakteristik perseorangan maka peserta didik yang lambat akan selalu kekurangan waktu untuk menyelesaikan tugas belajar, dan sebaliknya peserta didik yang cepat akan selalu kelebihan waktu.

5) Mengacu pada hasil belajar. Hasil PAI mencakup hasil langsung dan hasil pengiring dan hasil pembelajaran terbentuk secara kumulatif yang merupakan ramuan dari sejumlah peristiwa pembelajaran PAI.

6) Mengacu pada kemudahan belajar. Guru PAI tidak hanya sebagai sumber belajar dan sumber nilai, tetapi juga menampilkan diri sebagai orang ahli dalam menata sumber belajar PAI dan mampu mengintegrasikan ke dalam tampilan dirinya, menampilkan diri sebagai satu komponen terintegrasi dari seluruh sumber belajar PAI. Maka tidak RPP mengacu pada upaya membuat peserta didik belajar dengan mudah, cepat, menyenangkan, mengesankan dan menarik hati nurainya.

7) Mengacu pada interelasi variabel pembelajaran. Hasil pembelajaran mencakup semua akibat yang muncul dari penggunaan metode pembelajaran PAI tertentu pada

${ }^{21}$ Muhaimin, Suti'ah, and Nor Ali, Paradigma Pendidikan Islam: Upaya Mengefektifkan Pendidikan Agama Islam Di Sekolah, ed. Siti Lailan Azizah (Bandung: Rosda Karya, 2012). 
kondisi tertentu. Hasil RPP PAI yang baik mampu meningkatkan keefektifan, keefisienan dan daya tarik pembelajaran PAI.

8) Mengacu pada kualitas metode pembelajaran PAI. Tiga prinsip dalam penetapan metode pembelajaran PAI yang optimal yaitu; 1) tidak satu metode pembelajaran PAI yang unggul untuk pencapaian semua tujuan dalam semua kondisi pembelajaran,

2) strategi dan metode pembelajaran yang berbeda memiliki pengaruh yang berbeda dan konsisten pada hasil pembelajaran PAI, 3) kondisi pembelajaran yang berbeda bisa berpengaruh secara konsisten pada hasil pembelajaran PAI.

Apabila perencanaan sudah tersedia, fungsi guru bergeser dari mengajar ke membelajarkan. Seiring dengan itu tugas guru / pendidik bukan menjadi lebih ringan tetapi lebih rasional dan menghargai orang yang belajar. Sehingga istilah guru / pendidik sebagai fasilitator dan motivator menjadi tepat. Tentu saja sebagai pembimbing dan pengarah guru juga sekaligus sebagai evaluator.

\section{c. Urgensi Evaluasi Keberhasilan Pendidikan}

Disamping seorang guru / pendidik Agama Islam profesioanl membuat penceranaan pendidikan. Di lain pihak tujuan pendidikan yang begitu mulia sebagaimana diamanatkan oleh GBHN tentu tidak akan tercapai kalau para pendidik (guru) tidak memiliki sifat-sifat yang baik, santun dan berakhlak yang diharapkan mampu ditransfer kepada anak didik. Bagaimana anak didik menjadi iman dan bertaqwa kalau tidak diberi contoh bagaiamana bertindak layaknya orang yang beriman dan bertaqwa. Bagaimana seorang murid menjadi disiplin, kerja keras dan sebagainya, kalau siguru sendiri pemalas dan tidak mengenal tata tertib dan disiplin.

Demikian juga sifat-sifat lainnya, harus mampu dan menjadi sosok teladan bagi murid-muridnya. Apabila sifat-sifat itu tidak mampu dan tidak dimiliki oleh seorang pendidik, maka wajar seorang guru tidak bisa disebut guru / pendidik yang profesional. Maka tidak salah banyak para guru yang gagal dalam menjalankan profesinya sebagai guru yang uswatun khasanah, yang membimbing anak didiknya untuk kebahagiaan dunia dan kebahagiaan di akhirat kelak nanti. Bisa juga terjadi seorang guru mampu menjalankan profesi dengan baik, dengan cara mentrasfer ilmu pengetahuan (knowlodge) semata. Tetapi sebenarnya ia gagal dalam profesi itu, karena dimata anak didiknya ia tak lebih dari seorang manusia yang mencari materi semata dengan ilmu yang dia ajarkan. Dia gagal mendidik mental / spiritual dan ruhani anak muridnya, karena tiada contoh yang mampu ia berikan sebagai uswatun hasanah. Akibatnya seorang guru jatuh kedalam kehinaan dan tak bermartabat dimata murid-muridnya. Karena seorang guru / pendidik hanya mengisi otak 
anak didiknya dengan ilmu pengetahuan lupa mengisi kerohanian sebagai dimensi spirtual bagi anak didiknya.

Urgensi evaluasi keberhasilan pendidikan dalam Islam bukan dinilai semata-mata dari model KBK. Tujuan pendidikan Islam adalah adanya keseimbangan kebutuhan jasmani dan rohani. Oleh sebab itu tujuan pendidikan Islam adalah untuk:

1) Membentuk akhlak yang mulia. Hal ini sesuai dengan hadis nabi: "Sesungguhnya aku (Rasulullah Muhammad Saw) diutus untuk memperbaiki akhlak manusia

2) Membentuk aqidah yang benar. Hal ini sesuai dengan al-Qur'an: “Aku tidak ciptakan Jin dan Manusia kecuali untuk beribadah kepada-Ku” (QS. adz-Dzariyat, $51: 56$ )

3) Memajukan peradaban umat. Hal ini sesuai dengan tujuan pendidikan sebagai agen pembaharu. Belajar adalah merupakan kata kunci. Wahyu pertama diterima Rasulullah adalah perintah untuk membaca "اقراء". Membaca adalah proses belajar dan mengajar. Sebagaimana firman Allah:" Bacalah dengan (menyebut) nama Tuhanmu Yang Menciptakan. Dan telah menciptakan manusia dari segumpal darah. Bacalah, dan Tuhanmulah Yang Maha Pemurah. Yang mengajar (manusia) dengan perantaraan kalam. Dia mengajarkan kepada manusia apa yang tidak diketahuinya”, (QS. al-`Alaq: 1 - 5 )

\section{Pendidikan Agama Islam melalui Keteladanan.}

Moral dapat diartikan sebagai suatu pemikiran yang diterima untuk ukuran, yang benar, pada waktu perbuatan manusia nampak dalam kehidupan sehari-hari. Sedangkan akhlak diambil dari bahasa Arab, plural dari akar kata khuluq, yang diartikan sebagai perangai. Kehalusan (pembenaran) perbuatan manusia nampak pada waktu orang berbuat, sering dinamakan sopan santun. Sesuai dengan arti akhlak itu sendiri, maka tergambar ihwal yang menyangkut laku perbuatan dan norma yang dijadikan sebagai tolak ukur dalam menilai baik atau buruk. Laku perbuatan yang mengandung nilai akhlak tentunya tidak begitu saja lahir dalam kenyataan tanpa adanya aktivitas dari faktor endogen dan faktor eksogen.

Faktor endogen lahir dari diri manusia itu sendiri melalui dorongan-dorongan, hawa nafsu, insting, hasrat dan kata hati. Sedangkan faktor eksogen lahir dari lingkungan manusia berupa pendidikan, tradisi, norma, sosial, norma, agama dan sebagainya. Disinilah posisi seorang guru diposisikan, guru adalah merupakan contoh teladan bagi muridnya, masyarakat lingkungannya, bahkan bangsa dan negaranya. Guru harus punya moralitas dalam kehidupan, dan salah satu ajaran Islam yang paling mendasar adalah keluhuran akhlak. 
Penanaman nilai-nilai akhlak dan moralitas seorang guru merupakan sifat keteladan. Karena al-Qur'an yang diturunkan oleh Allah Swt kepada Rasul Muhammad Saw. adalah sumber akhlak dan budi pekerti untuk manusia. Sifat ini sangat menentukan perjalanan kerasulan Muhammad, dan juga sangat menentukan perjalanan kehidupan manusia, karena hadis nabi mengatakan : "Sebaik-baik diantaramu, yaitu yang lebih baik akhlaknya”. H.R. Syaikhani

Bahkan Rasulullah Muhammad Saw diutus untuk menyempurnakan akhlak manusia. Hal ini sesuai dengan hadis Nabi :

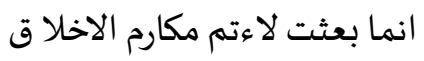

Sesungguhnya aku (Muhammad) diutus untuk menyempurnakan akhlak

Menyempurnakan dalam arti memberi memperbaiki dan memberi contoh bagiamana seharusnya manusia berakhlak dalam menjalani kehidupan. Contoh yang paling konkrit yang telah diketahui secara umum, bahwa Rasulullah itu terpuji yaitu memiliki sifat siddik, amanah, tablig dan fathanah. Sifat-sifat seperti ini harus ada bagi seorang pendidik. Seorang guru dapat menenamkan nilai-nilai moralitas atau akhlak melalui keteladan sifat-sifat terpuji ini. Profesi guru adalah profesi yang dihargai dan dijadikan contoh oleh anak didiknya, oleh sebab itu seorang guru harus mampu mentransfer nilai-nilai moralitas keteladan dengan jalan, antara lain:

1) Berlaku Siddik. Siddik artinya benar. Sifat ini adalah sifat manusia yang sangat urgen sekali dalam kehidupan. Apabila seorang guru oleh muridnya diragukan kebenaran apa yang disampaikan, tentu keberhasilan pendidikan tidak akan tercapai dengan baik. Seorang pendidik dalam setiap perkataan yang diucapkan baik itu materi pelajaran atau janji, kebenarannya harus dapat dipertanggungjawabkan

2) Berlaku Amanah. Amanah artinya dipercaya. Sifat ini terkait dengan kepemimpinan, atau tanggung jawab terhadap suatu jabatan. Seorang guru mempunyai tanggung jawab (amanah) yang dia pikul, untuk mentransfer pengetahuan yang dimilikinya kepada anak didiknya. Amanah ini terkait dengan rasa ikhlas dalam menjalankan tugas keguruan, untuk meningkatkan sumberdaya manusia Indonesia yang mampu bersaing di era global.

3) Berlaku Tablig. Tablig artinya menyampaikan. Sifat ini terkait dengan cara dan bagaimana teknis penyampaian materi ke anak didik. .Sekarang ini menyampaikan materi adalah kurikulum yang berbasis kompetensi.

4) Berlaku Fathanah. Fathanah artinya bijaksana, cerdas. Sifat ini harus dimiliki oleh seorang guru. Seorang guru merupakan ensiklopedia bagi anak didiknya, sekurang- 
kurangnya pada ilmu yang menjadi kajiannya, ia senantiasa akan menjadi tumpuan pertanyaan mereka. Oleh sebab itu seorang guru harus cerdas untuk dapat memberikan jawaban yang memuaskan bagi murid-muridnya

Sebenarnya sifat-sifat tersebut di atas adalah sifat Rasul Muhammad Saw, yang memang harus dimiliki oleh setiap pendidik jika ingin menjadi sorang contoh dan teladan bagi lingkungannya. Disamping banyak lagi nilai-nilai moralitas yang dapat di bangun untuk menjadi guru yang uswatun hasanah. Seperti sifat kepemimpinan, keadilan, keikhlasan, kebersamaan dan lain sebagainya.

\section{Pendidik Agama Islam berjiwa kepemimpinan}

Guru yang berhasil adalah guru yang mempunyai jiwa kemimpinan. Yang perlu digaris bawahi ialah bahwa pendidikan modern sekarang ini menekankan perlunya dalam proses pengajaran hendaklah terjadi interaksi aktif dan kerjasama yang baik bernilai edukatif antara pendidik dan anak didik. Untuk kesempurnaan interaksi dan kerjasama yang baik antara pendidik dalam proses pengajaran dan anak didik dalam belajar, perlu diperhatikan langkah-langkah sebagai berikut:

1) Pendidik hendaklah senantiasa mempersiapkan situasi dan kondisi yang dapat membantu anak didik mengutarakan kepribadiannya dan mendapatkan pengalaman serta pengetahuan atas kesadaran dan kemauannya sendiri. Karena proses pengajaran tidak akan berhasil mencapai tujuannya, kecuali jika disertai dengan proses belajar dari anak didik yang muncul dengan kesadaran dan kemauan sendiri. Hal ini sejalan dengan pendapat pendidikan modern.

2) Seorang pendidik hendaklah selalu memotivasi mereka (anak didik) untuk banyak membaca, karena membaca adalah kuncinya ilmu pengetahuan, menambah wawasan dalam berbagai bidang, yang lebih khusus lagi adalah banyak membaca dibidang yang diminati dan digeluti oleh si anak didik untuk bekal pengetahuan.

3) Pendidik hendaklah memiliki sifat kasih sayang, lemah lembut dan tidak kasar kepada mereka. Sifat ini dinilai penting karena dapat menimbulkan rasa percaya diri dan rasa aman bagi anak didik sehingga memotivasi mereka untuk belajar sungguhsungguh dan dengan kemauan sendiri

4) Pendidik hendaklah selalu memperhatikan perkembangan akal anak didik dan kemampuan mereka menerima berbagai ilmu dan keterampilan ynag diajarkan oleh pendidik. 
5) Pendidik harus mampu menjadikan dirinya seorang keteladanan bagi anak didiknya, karena faktor keteladanan adalah merupakan dambaan anak didik yang ingin mencontoh idola yang di tokohkan yaitu sang guru.

Hubungan pendidik dan anak didik menurut dalam pendidikan modern cenderung ingin memposisikan pendidik yang demokratis dan anak didik yang kreatif dinamis dan berpengetahuan luas. Pemikiran ini sangat relevan dengan hubungan pendidik dan anak didik yang diinginkan oleh pendidikan Islam.

\section{Penutup}

Karateristik Pendidikan Agama Islam adalah penekanan kepada pencarian ilmu pengetahuan, pengusaan dan pengembangan atas dasar ibadah kepada Allah Swt. Oleh karenanya, pendidikan dalam agama Islam adalah life long education. Sejalan dengan era globalisasi dengan berbagai macam tantangannya maka pendidikan agama Islam dituntun untuk melahirkan berbagai macam paradigama baru dalam pendidikan yang mengacu kepada berbagai macam komponen pendidikan. Pendidikan Agama Islam menekankan karakter pengakuan tehadap potensi dan kemampuan seseorang untuk berkembang, oleh karenanya, pendidik memiliki peran central dalam membangun generasi bangsa yang unggul. Pendidik atau guru profesional adalah mereka yang mampu melahirkan generasi bangsa dengan jiwa kepemimpinan, menjadi teladan, motivatoris, berwawasan luas, kreatif dan demokratis. Lewat pendidik yang profesional yang memiliki etos kerja dan komitmen yang tinggi, menejemen berbasis system dan infrastuktur yang kuat, sumber daya yang memadai, serta standar yang unggul yang tergambar melaui profesionalitas dalam desain serta model pembelajara, perencanaan serta evaluasi pemeblajaran.

\section{E. Daftar Pustaka}

A'la, Abd. "Pendidikan Agama Yang Mencerahkan.” Kompas. Jakarta, 2002.

al Attas, Naquib. Filsafat Dan Praktik Pendidikan Islam. Bandung: Mizan, 2013.

Azra, Azyumardi. Pendidikan Islam Tradisi Dan Modernisasi Di Tengah Tantangan Milenium III. Jakarta: Kencana Prenada Media Group, 2012.

Fakhrudin, Agus. "Nilai-Nilai Karakter Dalam Kebijakan Nasional Pengeloaan Guru." In The First Internatonal Conference on Islamic Education, 71-72. Bandung: Prodi Pendidikan Ilmu Agama Islam UPI, 2016.

Hasan Sulaiman, Fathiyah. Al-Mahabut Tarbawi Inda Al-Ghazali (Sistem Pendidikan Versi Al-Ghazali. Edited by Fathurrahmat. Bandung: Al Ma'arif, 1986. 
Khobir, Abdul. "Pendidikan Agama Islam Di Era Globalisasi." Forum Tarbiyah 1, no. 1 (2009): 5-6.

Miller, Jhon P. Holistic Learning and Spirituality Education, Braeking New Ground. New York AS: State University of New York Press, 2005.

Muhaimin, Suti'ah, and Nor Ali. Paradigma Pendidikan Islam: Upaya Mengefektifkan Pendidikan Agama Islam Di Sekolah. Edited by Siti Lailan Azizah. Bandung: Rosda Karya, 2012.

Nata, Abuddin. Kapita Selekta Pendidikan Islam. 1st ed. Depok: PT Raja Grafindo Persada, 2012.

—. Studi Islam Komperhensif. Jakarta: Prenada Media Grup, 2011.

—. Teori Dan Perilaku Organisasi Pendidikan Islam. Jakarta: UIN Jakarta Press, 2011.

Shindunata. Menggagas Pardigma Baru Pendidikan Demokratisasi, Otonomi, Civil Society, Globalisasi. Yogyakarta: Kanisius, 2000.

Sukmadinata, Nana Syaodih. Pengembangan Kurikulum. Bandung: Rosda Karya, 1997.

Zarkasy, Abdullah Syukr i. "Madrasah Pemberdayaan Dan Peningkatan Mutu." MP3A 1, no. 1 (2005): 92. 